\title{
Weighing in the Issue of Heavy Schoolbags Carried by Pupils in Primary School 小學生書包的重量：在新加坡的研究
}

\author{
Michael CHIA Serena TAN Abbie TAN \\ Soot Mei TAN Bervyn LEE
}

Physical Education and Sports Science,

National Institute of Education,

Nanyang Technological University, SINGAPORE

\author{
謝永和賽麗哪・陳艾比・陳 \\ 陳素梅博文・李 \\ 新加坡南洋理工大學 \\ 國立敉育學院體育與運動科學組
}

\begin{abstract}
The issue of heavy schoolbags is a common concern among educationists, parents and school children. The pervasiveness of the carriage of heavy schoolbags among 482 primary school pupils from two schools was studied. Participants were grouped according to sex and primary levels (i.e. P1 \& P2, aged 7-8 years and P3 \& P4, aged 9-10 years). Body mass with and without schoolbags was measured on a single weekday using a calibrated weighing machine. Pupils also completed a 10-item questionnaire that solicited responses about the type of schoolbag carried, the number of bags carried, how the bags were carried, whether they felt that their bags were too heavy, if they had suffered pain, soreness or numbness from carrying the schoolbags and information about their travel to and from school. Results revealed that pupils carried bags that weighed about $15 \%$ to $17 \%$ of body weight. The figures also indicated that $60.4 \%$ of the lower primary group (P1 and P2) exceeded the guideline of $3.5 \mathrm{~kg}$ outlined by the Ministry of Education (Singapore) for schoolbags, and 55.8\% exceeded the guideline of $4.5 \mathrm{~kg}$ for the middle primary group (P3 and P4). Participants also reported that they carried bags that were too heavy, and experienced pain, soreness or numbness in the neck, shoulders or back. Results of this study indicate that more can be done to reduce the physical load of schoolbags for primary pupils. Implications of the findings are discussed, including two current initiatives to create an electronic learning environment within the school compound where pupils can access textbook and workbook information.
\end{abstract}

Key words: Heavy schoolbags, primary school pupils

\section{摘 要}

在發展中國家與發澾國家中，學齡兒童的書包重量不當是引起青年期或成年后腰背部疼痛的常見原因之一，往往是由於書包過重 所致。本文對新加坡兩所小學進行了調查, 結果提示學生書包的重量普遍超過健康指南所規定的最大重量。因此, 在提高健康水平及 健康教育方面還需做大量的工作，以減輕小學生，特別是低年級學生體力上的負荷。 


\section{Introduction}

Many parents and teachers in Singapore have expressed concern over the heavy schoolbags carried to school on a daily basis by young school children. It is common to see seven-year old boys and girls hunched over with bags carried on their backs that are too heavy and too big for their smaller frames. A survey conducted by the American Academy of Orthopaedic Surgeons (Wright \& Schuetz, 1999) revealed that $58 \%$ of orthopaedists handled medical cases of school-going children who complained of back and shoulder pain caused by heavy backpacks. The survey concluded that the extra stress placed on the spine and shoulder from heavy loads caused unnecessary medical problems in children. Health experts caution that overloading the spine and the child's capacity to carry loads, particularly in the early years of school life and up till early adulthood, can cause physical changes to the spine that lead to acute injury such as musculoskeletaltype pain that may become chronic (Chia, Leong \& Quek, 2002).

The issue of heavy schoolbags is apparently not contained within geographical boundaries - people from Australia, New Zealand, India, Brazil, Poland, Italy, Egypt, United States of America, and Hong Kong have raised similar concerns (Whittfield \& Legg, 2001). In 1997, the Government of Ireland announced the set up of an expert working group to examine the problems that arise from the weight of schoolbags, and to formulate proposals to ameliorate possible ill effects (Martin, 2001).

The stress of heavy schoolbags on the immature spine of young people and the concomitant poor posture adopted are identified as potential antecedents for more serious and longer-term back problems in adulthood (Voll \& Klimt, 1977). Although controlled studies that link the two together are lacking, it would be prudent not to ignore the potential harm of carrying too heavy a load over a long period of time for a child. The old adage 'as the twig is bent, so grows the tree' is apt. The issue therefore warrants research attention.

Carrying heavy schoolbags can exacerbate existing postural and skeletal problems like scoliosis or curvature of the spine, and cause balance problems when crossing busy roads or climbing stairs. Biomechanical studies on youths aged between 11 and 13 years show that carriage of backpacks promote a significant forward lean of the head and trunk compared with normal walking without a backpack (Grimmer, Williams \& Gill, 1999). Another study showed that carrying a heavy schoolbag significantly reduces stride length and increases stride frequency compared to normal walking, thereby reducing the support phase of the gait (Pascoe, Pascoe, Wang, Shim \& Kim, 1997). The same study also revealed that one-strap packs promoted lateral spinal bending and shoulder elevation, while two-strap backpacks significantly reduced the pack carrying stresses on the back. In another study, researchers examined the standing posture of school-going pupils with a backpack and without a backpack (Grimmer, Williams \& Gill, 1999). Results revealed significant associations between adolescent head-on-neck posture, backpack weight, and anthropometric features, with greatest changes in craniovertebral angle occurring in the youngest group of pupils. The result indicates the greater vulnerability of youth to back stress. There is therefore a need for safeguards to ensure the good back health of young people.

Evidence on the pervasiveness of heavy schoolbags carried by young people is growing. A study conducted in Milan that involved 237 children aged between 11 and 12 years, monitored over a period of three weeks in 1999, showed that the weight of schoolbags carried by the pupils was 9 . $3 \mathrm{~kg}$ or $22 \%$ of their body mass (Negrini, Carabolana \& Sibilla, 1999). Another study conducted in New Zealand, which involved 140 secondary pupils found that nearly $73 \%$ of teenagers reported on-going pain attributed to carrying bags to school that weighed up to twice the recommended safe weight for adults to carry (Whittfield \& Leggs, 2001). In the cited study, the pupils carried an average load of $6.6 \mathrm{~kg}$ everywhere they went in school. $44 \%$ of the pupils surveyed reported that they experienced pain in their necks in the last week, $58 \%$ reported pain in their shoulders, 35\% said that their upper backs hurt and 35\% suffered from lower back pain. Of great concern was the finding that younger pupils carried heavier loads than their older counterparts - the equivalent of 13 . $2 \%$ of body mass in younger pupils compared to $10.3 \%$ of body mass in older pupils.

Some research data suggest that parental knowledge of contents of overweight schoolbags carried by children is negatively associated with the weight of the schoolbag. Forjouh and his colleagues (Forjuoh, Lane, Schuchmann \& Mason, 2001) reported that children of parents who checked the contents of their schoolbags carried significantly lighter loads and also fewer textbooks than children whose bags were never checked or weighed by their parents. These data suggest that there are merits in educating parents to pay greater attention to what goes into the schoolbags of pupils. 
Recommendations for weight limits for carriage of loads on the backs of young people are somewhat varied, with the American Chiropractic Association (ACA) (10) recommending a limit of $10 \%$ of the child's body mass, to not more than $20 \%$ of body mass for young people and adults, as suggested by the American Academy of Orthopaedic Surgeons (Wright \& Schuetz, 1999). Most health experts however recommend a $15 \%$ of body mass figure as the upper limit for young people and a $10 \%$ of body mass reference value for younger children (Chia, Leong \& Quek, 2002). In Singapore, the Ministry of Education recommends that Primary 1 pupils (age 6-7 years) carry bags that weigh less than $3 \mathrm{~kg}$. Pupils in primary 2 (age 7-8 years) can carry schoolbags that weigh up to 3 . $5 \mathrm{~kg}$ while the bags of pupils in primary 3 and 4 (age 810 years) should not be heavier than $4.5 \mathrm{~kg}$ (Davi, 2001). These recommendations are proposed after taking into account the average body mass of pupils in the different age groups.

Unlike some countries where published studies on the heavy schoolbag issue are available, the extent of the problem in Singapore is mainly anecdotal and there is a need for research data on the matter. Therefore, the purpose of the study was to investigate the pervasiveness of the heavy schoolbag problem in two primary schools in Singapore and also make recommendations to ameliorate the problem where necessary.

\section{Methods}

Participants were 482 primary school boys and girls from an Eastern and Western precinct in Singapore and the method of sampling was purposive (Sherill \& O'Conner, 1999), so that the two schools that were involved in the study had pupil cohorts that were representative of the majority of primary schools in Singapore. Pupils were grouped according to sex and primary levels (i.e. P1 \& P2, aged 7-8 years and P3 $\&$ P4, aged 9-10 years). Informed written consents from the pupils' parents were obtained but there was no direct mention that the schoolbags would be weighed.

In each of the schools, a trained physical education teacher measured the body mass of the pupils, with and without the schoolbags, using the same calibrated weighing scale (Avery 3306 ABV beam balance) on a single weekday. Pupils also completed a 10-item questionnaire (see Table 2) in the same session. Questionnaire items solicited information about the type of schoolbag pupils carried, the number of bags carried, how pupils carried their bags, whether pupils found their bags heavy or not, and information about how pupils traveled to and from school.

Preliminary data analyses revealed no significant differences in the body mass of the pupils and the weight of the schoolbags between the two primary schools. The data of the two schools were subsequently merged. Data garnered were stored and subsequently analysed using standard software (SPSS for Windows, Version 10.0). Relevant descriptive data (means standard deviations; and percentages) of the pupils and schoolbag information were generated. The level of statistical significance was set at $\mathrm{p}<0.05$.

\section{Results}

The data presented in Table 1 is a summary of the descriptive characteristics of the pupils, organised by sex and primary level groupings, and information about issue of heavy schoolbags based on the recommendations proposed by different authorities. 
Table 1. Data of Pupils, Bag Weight and Extent of Overloading of Schoolbags.

\begin{tabular}{ccc}
\hline \multicolumn{3}{c}{ Primary 1 \& 2 group (age 7-8 years old) } \\
\hline Sex & Boys (N=124) & Girls (N=116) \\
Body mass (kg) & $23.3 \pm 4.9$ & $22.1 \pm 4.6$ \\
Mass of bag (kg) & $3.9 \pm 0.9$ & $3.8 \pm 1.0$ \\
Bag-to-body mass (\%) & $17.1 \pm 5.5$ & $16.5 \pm 5.5$ \\
Recommendation for mass of schoolbag & \\
$\begin{array}{c}\text { Above 10\% of body mass } \\
\text { (ACA) }\end{array}$ & 93.5 & 62.2 \\
$\begin{array}{c}\text { Above 15\% of body mass } \\
\text { (ICPA)) } \\
\text { Mass of bag above 3.5 kg } \\
\text { (MOE, Singapore) }\end{array}$ & 63.7 & 60.2 \\
\hline
\end{tabular}

Primary 3 \& 4 group (age 9-10 years old)
Sex
Boys $(\mathrm{N}=123)$
Girls (N=119)

$$
\begin{aligned}
& \text { Body mass (kg) } \\
& \text { Mass of bag (kg) }
\end{aligned}
$$$$
31.7 \pm 8.4
$$$$
31.7 \pm 9.2
$$

$5.1 \pm 1.4$

$4.6 \pm 1.3$

Bag-to-body mass (\%)

$16.9 \pm 5.8$

$15.5 \pm 5.7$

Recommendation for mass of schoolbag

Above $10 \%$ of body mass (ACA)

Above $15 \%$ of body mass (ICPA)

Mass of bag above $4.5 \mathrm{~kg}$ (MOE, Singapore)
88.6

84.0

64.2

60.3

ACA: American Chiropractic Association; ICPA: International Chiropractic Pediatric Association; MOE: Ministry of Education in Singapore. 
In Table 2, results of the 478 respondents out of the 482 participants (99.1\% response) to the survey are summarized. Four participants did not complete the questionnaire.

Table 2. Questionnaire Responses of the Participants ( $\mathrm{N}=478$ ).

\begin{tabular}{|c|c|c|c|}
\hline & Question (Q) & Choices & Percentage $(\%)$ \\
\hline \multirow[t]{2}{*}{1.} & \multirow{2}{*}{$\begin{array}{c}\text { Do you carry your own } \\
\text { bag(s) to and from school? }\end{array}$} & Yes & 92.1 \\
\hline & & No & 7.9 \\
\hline \multirow[t]{4}{*}{2.} & \multirow{2}{*}{$\begin{array}{l}\text { What type of bag(s) do } \\
\text { you carry to and from } \\
\text { school }\end{array}$} & $\mathrm{A}$ & 85 \\
\hline & & B & 2.2 \\
\hline & \multirow[t]{2}{*}{ (Appendix A) } & $\mathrm{C}$ & 4.8 \\
\hline & & $\mathrm{D}$ & 8 \\
\hline \multirow[t]{2}{*}{3.} & \multirow{2}{*}{$\begin{array}{l}\text { How many bags do you } \\
\text { carry to school? }\end{array}$} & One & 77.8 \\
\hline & & More than one & 22.2 \\
\hline \multirow[t]{3}{*}{4.} & \multirow{3}{*}{$\begin{array}{l}\text { How do you carry your } \\
\text { bag(s)? }\end{array}$} & Straps on one shoulder & 7.9 \\
\hline & & Straps on both shoulders & 82.1 \\
\hline & & Others & 10 \\
\hline \multirow[t]{2}{*}{5.} & \multirow{2}{*}{$\begin{array}{c}\text { Do you find your bag(s) } \\
\text { too heavy? }\end{array}$} & Yes & 63.5 \\
\hline & & No & 36.5 \\
\hline \multirow[t]{2}{*}{6.} & \multirow{2}{*}{$\begin{array}{l}\text { Have you suffered pain, } \\
\text { soreness, or numbness on } \\
\text { your neck, shoulders or } \\
\text { back from carrying your } \\
\text { schoolbag(s)? }\end{array}$} & Yes & 58 \\
\hline & & No & 42 \\
\hline \multirow{2}{*}{7.} & \multirow{2}{*}{$\begin{array}{c}\text { Do you pack your bag(s) } \\
\text { according to your class } \\
\text { timetable? }\end{array}$} & Yes & 77.8 \\
\hline & & No & 22.2 \\
\hline \multirow[t]{2}{*}{8.} & \multirow{2}{*}{$\begin{array}{l}\text { Do you keep some of your } \\
\text { books in the classroom or } \\
\text { in school? }\end{array}$} & Yes & 50.8 \\
\hline & & No & 49.2 \\
\hline \multirow[t]{2}{*}{9.} & \multirow{2}{*}{$\begin{array}{c}\text { How do you travel to and } \\
\text { from school? }\end{array}$} & On foot & 46 \\
\hline & & $\begin{array}{l}\text { By car, public transport or } \\
\text { by the school bus }\end{array}$ & 54 \\
\hline \multirow[t]{5}{*}{10.} & \multirow{5}{*}{$\begin{array}{l}\text { How much time do you } \\
\text { take walking \& carrying } \\
\text { your schoolbag to or from } \\
\text { school? }\end{array}$} & Less than $15 \mathrm{~min}$. & 63.5 \\
\hline & & Between 15 \& $30 \mathrm{~min}$. & 25.4 \\
\hline & & Between 30 \& $45 \mathrm{~min}$. & 9.5 \\
\hline & & Between 45 \& $60 \mathrm{~min}$. & 1.6 \\
\hline & & More than $60 \mathrm{~min}$. & 0 \\
\hline
\end{tabular}




\section{Disculssion}

Data collected from the study represent apparently the first study on the issue of heavy schoolbags carried by pupils in primary school in Singapore. Previous information had been mainly anecdotal. The main finding of the study was that the schoolbags carried by children between the ages of seven and 10 years old in primary schools exceeded the recommendations for safe weight carriage for schoolbags that are advanced by the American Chiropractic Association (ACA), the International Chiropractic Pediatric Association (ICPA) and that of the Ministry of Education (MOE) in Singapore.

From Table 1, it can be deduced that, according to the ICPA guideline, more than $60 \%$ of the pupils exceeded the recommended safe value in all groups except for girls in the Primary 3 and Primary 4. However, according to the ACA guideline, up to $93.5 \%$ (Primary 1and Primary 2) and 88. 6\% (Primary 3 and Primary 4) of the pupils carried schoolbags that weighed more than $10 \%$ of body mass. This information was buttressed by $63.5 \%$ of the pupils reporting that they found the bags too heavy (see questionnaire response to Q5 in Table 2). When using recommendations furnished by the Ministry of Education (MOE) in Singapore (Davi, 2001), between 51 and $61 \%$ of the 282 pupils studied still exceeded MOE recommendations (see Table 1).

The data mirrored findings conducted in other countries. For instance, an Italian study based on 237 adolescents aged 11 and 12 years revealed that the average weight carried in backpacks over three weeks was $9.3 \mathrm{~kg}$ or $22 \%$ of the adolescents' body mass (Negrini, Carabolana \& Sibilla, 1999). Forjuoh et al (2001) reported that $25.3 \%$ of 744 pupils in three elementary schools in Texas, U.S.A., carried backpacks that weighed more than $10 \%$ of body mass. Researchers from Auburn University, U.S.A., reported that the average load carried by 421 young people studied was equivalent to $17 \%$ of body mass (Pascoe et al, 1997). These data confirm that the heavy schoolbags is a health concern in many countries.

The issue of too heavy a schoolbag should not be ignored as research has shown that overloading the backpack beyond the person's carrying capacity might alter walking gait, walking posture, cause shoulder pain, muscle soreness, localized numbness and back pain, which may lead to more serious back problems in the future, especially when the overloaded bag is inappropriately carried (Pascoe et al, 1997).
In the present study, it was reassuring that $85 \%$ of the pupils used a backpack-type bag with two shoulder straps (see Appendix A, choice A) and $82.1 \%$ of the pupils carried schoolbags on both shoulders using two bag straps (see questionnaire responses to Q1 and Q4 in Table 2). Still, a sizeable $63.5 \%$ of the pupils reported that the schoolbags that they carried were too heavy, and 58\% of the pupils reported that they had suffered pain, soreness or numbness in the neck, shoulders, or back, from carrying the schoolbags (see questionnaire responses to Q5 and Q6 in Table 2). This finding is consistent with the results reported in New Zealand (Whittfield \& Leggs, 2001).

A physically over-laden child is more likely to be not in balance when performing daily tasks of climbing and going down stairs, being less in control when cycling due to increased momentum, and when crossing roads (Chia, Leong \& Quek, 2002). This may increase the risk of accidents, especially when the majority of pupils spend a considerable amount of time walking to and from school on a daily basis (see questionnaire response to Q10 in Table 2).

Concern about overloading the young child with too heavy a schoolbag carried on their immature skeletal frames stem from early studies that demonstrated an association between stunted growth in peasant children and the carriage of heavy loads, as well as increasing numbers of young people who reported pain and injury caused by heavy schoolbags (Chia, Leong \& Quek, 2002). In the case of stunted growth, it should be noted that inadequate nutrition might also have been a factor. The concern with lower back pain among young people appears more legitimate, although there is little evidence, which show that serious pediatric conditions like scoliosis or curvature of the spine are due to carrying heavy schoolbags (Martin, 2001). Moreover, it should be noted that bone mass and bone density are especially enhanced with weight bearing type activities (including carrying a laden bag on the back), together with adequate intakes of calcium and Vitamin D during the childhood and adolescence (Chia, Leong \& Quek, 2002).

Survey information gleaned from Table 2 (see questionnaire response to Q7 in Table 2) suggest that one possible reason schoolbags weighed so much might be due to pupils not packing their schoolbags according to the day's time-table (at least $22.2 \%$ of the present sample). For many, the schoolbags were still too heavy despite $50.8 \%$ of the pupils keeping some of their workbooks, worksheets and exercise books in the classrooms instead of carrying the load in their bags (see questionnaire response to Q8 in Table 2). 
Apart from increasing the awareness and publicity of guidelines for safe weight carriage, parents can take an active part by checking on the contents that go into schoolbags. Forjuoh and his colleagues (2001) reported a negative relationship between parents' knowledge of the content of schoolbags and the weight of the schoolbag. Therefore, it appears that when parents take an active interest in what goes into their children's schoolbags, the bag load is lightened.

School principals and teachers can also take the lead with creative time-tabling that takes into account the load that pupils need to carry to school daily, and arranging for cupboard or desk space where pupils can leave non-core textbooks in class. Encouraging and allowing pupils time to complete required written work in class or during school-operating hours might also help. Worksheets or work on different subjects can be put on-line and computer accesses made available in school are also measures that can reduce the weight of schoolbags. Schools can seek funding to provide pupils with a full set of textbooks to be kept in class so that pupils can leave the other set of books at home for their own revision.
One promising development in Singapore is the creation of an electronic book project called the EduPAD ${ }^{\mathrm{TM}}$, which substantially reduces the need for hardcopy textbooks. The EduPAD $^{\mathrm{TM}}$ is a hand-held computer where textbook and workbook information can be accessed and downloaded easily. The device has been pilot tested in schools and weighs a fraction of an average schoolbag. Another potential solution to the heavy schoolbag issue is the creation of an electronic learning (elearning) environment within the school compound where information contained in textbooks can be accessed via computers or laptops, either through the network or through the wirelessenabled school environment. These initiatives can substantially reduce the weight of schoolbags.

\section{Conclusion}

The results of the study indicated that the issue heavy schoolbags carried on the backs of young people is a cause for concern. Up to $93.5 \%$ of boys and $92.2 \%$ girls in the lower primary school cohort carried schoolbags that exceeded the ACA guideline for safe bag carriage. More can be done to ameliorate this health concern, including the implementation of an e-learning environment in schools that could drastically reduce the need for textbooks.

\section{Appendix A. Types of Schoollbags Carried by the Participants.}

A

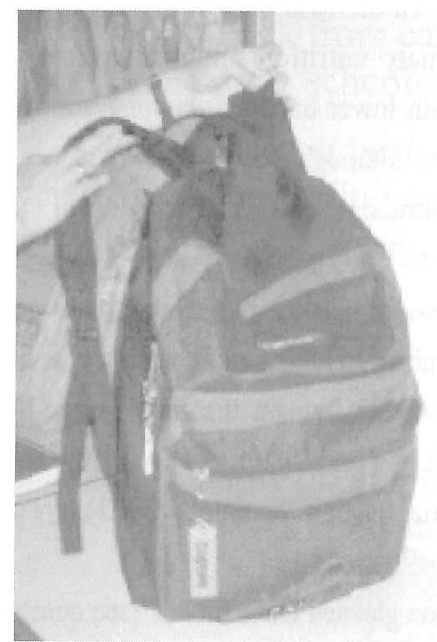

B

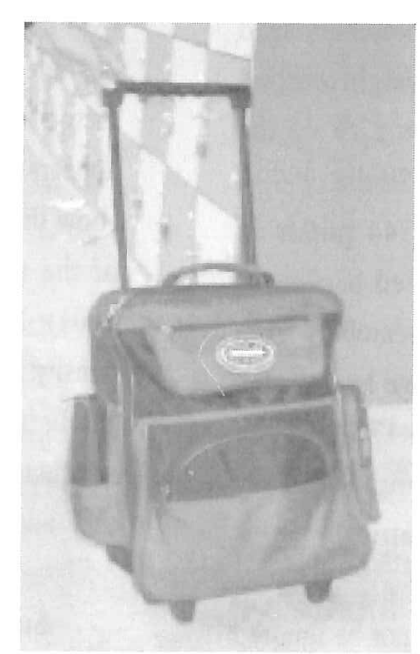

C

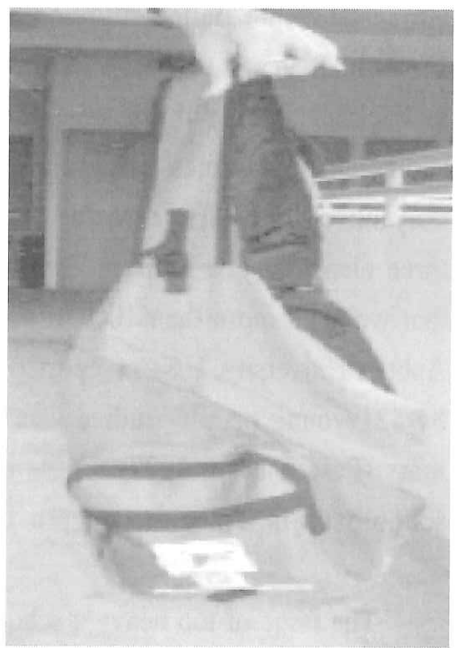

D

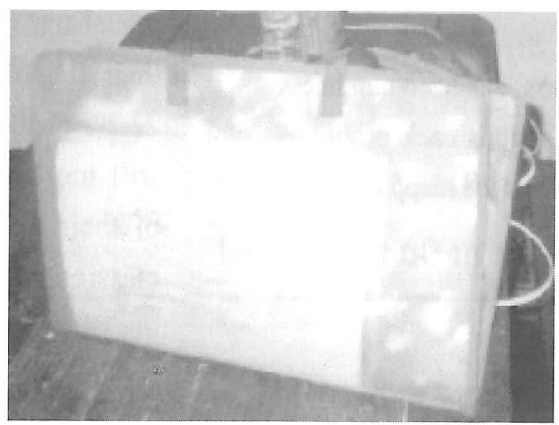




\section{References}

American Chiropractic Association (ACA). (2001). http://www. americhiro.org. Accessed 7 Dec 2001.

Chia, M., Leong L.K., \& Quek, J.J. (2002). Healthy, well and wise: take personal responsibility in daily effort for a life of wellness (2nd ed.). National Institute of Education Publication. Singapore, 1-302.

Davi, S. (September 30, 2002) Lightening the load. The Straits Times (Singapore).

Sherill, C. \& O' Conner, J. (1999). Guidelines for improving adapted physical activity research. Adapted Physical Activity Quarterly, 16 (1), 1-87.

Forjuoh, S.N. \& Lane, B. L, Schuchmann, J.A. \& Mason, S. (2001). Parental knowledge of the contents of heavy backpacks carried by elementary school children. $A$ \& $M$ University System Health Center. http://apha.confex. com. Accessed 7 Dec 2001.

Grimmer, K. A., Williams, M. T. \& Gill, T.K. (1999). The associations between adolescent head-on-neck posture, backpack weight and anthropometric features. Spine, 24 (5) 2262.

Martin, M. (2001). Problems arising from the weight of schoolbags. Department of Education and Science, Government of Ireland 1997. http://www.irlgov.ie/. Accessed 7 Dec 2001.
Pascoe, D.D., Pascoe, D. E., Wang, Y.T., Shim, D. M., \& Kim, C.K. (1997). Influence of carrying book bags on gait and posture of young children. Ergonomics, 40 (6), 631-41.

Negrini, S., Carabolana, R., \& Sibilla, P. (1999). Backpack as a daily load for school children. Lancet Journal, 354, 91-94.

Voll, H.J., \& Klimt, F. (1977). Strain in children caused by carrying schoolbags. Offentl Gesundheitswea, 39 (7), 369.

Whittfield, J. \& Legg, S. (2001). The pain of schoolbags. Massey News 2001. Massey University. http://masseynews. massey.ac.nz/. Accessed 7 Dec 2001.

Wright, A.J. \& Schuetz, T. (1999). Backpacks can cause students problems. Orthopaedics Update. http://www.assos.org/. Accessed 7 Dec 2001.

\section{Correspondence:}

Dr Michael Chia

Physical Education and Sports Science

National Institute of Education

Nanyang Technological University

1 Nanyang Walk

Singapore 637616

Tel: $65-67903701$

Fax: 65-68969260

Email: yhmchia@nie.edu.sg 